Abstract 237 Table 1 Distribution of ischaemic stroke subtypes in patients with SLE according to TOAST classification

\begin{tabular}{|l|c|c|}
\hline Ischemic stroke subtypes & $\mathrm{N}(\%)$ & $\begin{array}{l}\text { Age in years at first event } \\
\text { (median, range) }\end{array}$ \\
\hline Any ischemic stroke & $56(100 \%)$ & $52(17.84)$ \\
\hline Large artery artherosclerosis (LAA) & $7(12 \%)$ & $55(34-67)$ \\
\hline Small arterial occlucion (SAO) & $9(16 \%)$ & $63(51.84)$ \\
\hline Cardioembolic stroke (CE) & $12(21 \%)$ & $57(23.70)$ \\
\hline Other determined etiology (OE), all APS & $19(33 \%)$ & $42(18-74)^{* *}$ \\
\hline Undetermined etiology (UE) & $9(16 \%)$ & $56(25.73)$ \\
\hline
\end{tabular}

"Patients with OE/APS strokes were younger, as compared to all other stroke subtypes, $\mathrm{p}=0.003$

Abstract 237 Table 2 Association of the risk allele, STAT4 single nucleotide polymorphism (SNP) rs10181656 (G), in SLE patients with ischaemic stroke overall and stroke subtypes, specified according to the TOAST classification

\begin{tabular}{|l|c|c|c|c|c|}
\hline Stroke type & MAF\% & $\begin{array}{c}\text { OR (95\% CI) vs. } \\
\text { Controls N=658 } \\
\text { MAF 22.1\% }\end{array}$ & $\begin{array}{c}\text { p-value } \\
\text { Vs. } \\
\text { Controls }\end{array}$ & $\begin{array}{c}\text { OR (95\% CI) vs. } \\
\text { Non-stroke SLE, } \\
\text { N=517 } \\
\text { MAF 31.9\% }\end{array}$ & $\begin{array}{c}\text { p-value vs. } \\
\text { Non-stroke } \\
\text { SLE }\end{array}$ \\
\hline $\begin{array}{l}\text { Any ischemic } \\
\text { stroke N=56 }\end{array}$ & 33.7 & $3.3(2.2-4.9)$ & $<0.0001$ & $2.0(1.3-2.9)$ & 0.0005 \\
\hline $\begin{array}{l}\text { Small artery } \\
\text { occlusion N=9 }\end{array}$ & 27.8 & $1.4(0.5-3.8)$ & 0.57 & $0.8(0.3-2.3)$ & 0.71 \\
\hline $\begin{array}{l}\text { Large artery } \\
\text { occlusion N=7 }\end{array}$ & 21.4 & $1.0(0.3-3.5)$ & 1.00 & $0.6(0.2-2.1)$ & 0.56 \\
\hline $\begin{array}{l}\text { Cardioembolic } \\
\text { stroke N=12 }\end{array}$ & 70.8 & $8.6(3.5-20.8)$ & $1.8 \times 10^{-8}$ & $5.1(2.1-12.5)$ & $6.7 \times 10^{-5}$ \\
\hline $\begin{array}{l}\text { Other } \\
\text { determined } \\
\text { etiology (all } \\
\text { APS) N=19 }\end{array}$ & 60.5 & $5.4(2.8-10.5)$ & $3.2 \times 10^{-8}$ & $3.2(1.7-6.3)$ & 0.0003 \\
\hline $\begin{array}{l}\text { Undetermined } \\
\text { etiology N=9 }\end{array}$ & 33.3 & $1.8(0.7-4.7)$ & 0.28 & $1.1(0.4-2.8)$ & 0.92 \\
\hline
\end{tabular}

$M A F=$ monoallele frequency, $\mathrm{N}=$ number of patients, $\mathrm{OR}=\mathrm{Odds}$ Ratio, $\mathrm{Cl}=$ Confidence interval

Results 56/69 patients with ischaemic stroke had charts with sufficient information for TOAST classification. Median age was $52(17-84)$ years, 91\% were female. All strokes classified as OC were attributed to APS. TOAST classification is presented in Table 1. Stroke of OE/APS and CE origin were associated with the STAT4 risk genotype as presented in Table 2.

Conclusions The majority of ischaemic strokes among SLE patients were of APS or CE origin. These two subtypes were associated with genetic susceptibility in the STAT4 gene. Patients with APS associated strokes were remarkably young. STAT4 genotype could, in addition to antiphospholipid antibodies and echocardiography, add information about stroke risk and help identify patients who will benefit from prophylactic anticoagulation treatment.

\section{HEMOPHAGOCYTIC SYNDROME IN SYSTEMIC LUPUS ERYTHEMATOSUS : A MONOCENTRIC REVIEW OF 13 CASES}

Z Tazi Mezalek*, W Ammouri, M Bourkia, H Harmouche, M Maamar, M Adnaoui. Avicenne hospital- Mohammed V university, Ibn Sina hospital, Rabat, Morocco

\subsection{6/lupus-2017-000215.238}

Background and aims In recent years hemophagocytic syndrome (HS) has been increasingly reported in patients with systemic lupus erythematosus (SLE).

Methods We reviewed the medical records of adult patients with SLE and HS for a recent 6 years period (2010-2015). The diagnosis of SLE was made using ACR criteria and of HS using Hunter criteria.

Results Among 110 consecutive patients, 13 (12 women) was identified having HS. The mean age was $37.69+/-11.4$ years (21-68). HS revealed lupus in 3 patients. Fever, pericarditis and splenomegaly were found in $100 \%, 54 \%$ and $46 \%$ at presentation of HS. Bone marrow aspiration indicated hemophagocytosis in all patients. Laboratory features were bicytopenia or pancytopenia, high C-reactive protein level (mean $93 \mathrm{mg} / \mathrm{L}$ ) hyperferritinemia (mean $11.082 \mathrm{ng} / \mathrm{ml}$ ), hypertriglyceridemia (mean $4.2 \mathrm{~g} / \mathrm{L}$ ) in all patients. All patients had anti-nuclear antibodies when the HS occurred. Serum complement C3 was low in 10 patients. HS was associated with a lupus flare in 8 patients. Infections was diagnosed in 11 patients. Both conditions was considered present in 6 patients.

Corticosteroids were initially administered in all patients. Immunosuppressant therapy was used together with corticosteroids in 7 patients. Intravenous immunoglobulin was given in 3 cases. Anti-tuberculosis treatment was used also as first line treatment in 4 patients with life threatening presentation. All patients had a good outcome with a mean follow-up of 25 months.

Conclusions The occurrence of HS was most frequently associated with the SLE disease activity and bacterial infection. Profound cytopenia, high SLEDAI score are the characteristics of SLE patients with HS in our series.

\section{DEMOGRAPHY, CLINICAL AND IMMUNOGICAL PROFILE OF SYSTEMIC LUPUS ERYTHEMATOSUS PATIENTS FROM A TERTIARY CARE CENTRECENTER IN INDIA}

V Vasdev*, A Kumar, A Hegde, A MN, K Kishore, G Dharchoudhury. Army Hospital R and $R$, Rheumatology and Clinical Immunology, New Delhi, India

10.1136/lupus-2017-000215.239

Background and aims Systemic lupus erythematosus (SLE) is a systemic connective tissue disease involving multiple organ systems. There is lack of data on clinical and immunolgical profile in SLE patients from Indian subcontinent.

Objectives To describe clinical profile, outcome and laboratory profile of 226 SLE patients from records maintained at a tertiary care centre in India from $2008-2016$

Methods All patients who satisfied 1997 revised criteria of the ACR or the 2012 New SLICC Classification Criteria for SLE were included in the analysis. The medical records were analysed for clinical and laboratory profile of SLE patients.

Results A total of 226 SLE patients records were analysed. The female to male ratio was 9:1 (204 females, 22 males). The mean follow up was 4.2 years(Range 2-8 years). The overall mean age at diagnosis was 27 years (range 15-46 